\title{
SPATIAL LOCATION OF ARTISANAL MINING ACTIVITIES IN NIGER STATE AND ITS IMPLICATION TO THE ENVIRONMENT
}

\author{
Mustafa, Ibrahim Alhaji \\ Department of Geography, \\ Faculty of Arts and Social Sciences, \\ Nigerian Defence Academy Kaduna, Nigeria
}

Abstract- Niger State is blessed with abundant solid minerals deposits of different categories made up of precious metals, industrial minerals like coal, tin, gold, marble, limestone and others. These minerals have contributed to the growth and development of the state and the country at large. However, the sector is been frustrated by the activities of artisanal miners who uses local implement such as hoe, digger, and shovel in mining. The research aimed at locating and establishing the artisanal mining sites in Niger State and its implications to the environment. The data used are oral interviews, use of hand held GPS to pick coordinate of artisanal mining locations and from published works, Federal Ministry of mines and steel, government ministries year articles, and journals. The research revealed that Niger state has un even distribution of artisanal mining sites which is not adequately secured by the Government, it further shows that artisanal miners has greatly affected the environment in various ways which include altering of natural morphological look of the area, release of harmful chemical to the ozone layer, polluting the water body, causes erosions. The solution to these challenges is the revitalization of laws guiding mining in the state, government should call investors to the various site, provision of adequate security to checkmate mining activities, and general improvement in the standard of living through enabling economy policies that will emancipate many out of poverty.

Keywords: Artisanal, Environment, Geographical Information System, Miners, Niger State

\author{
Ezeamaka Cyril Kanayochukwu \\ Department of Geography, \\ Faculty of Arts and Social Sciences, \\ Nigerian Defence Academy Kaduna, Nigeria
}

\section{INTRODUCTION}

Nigeria is blessed with abundant solid minerals deposits of different categories made up of precious metals, stones and industrial minerals like coal, tin, gold, marble, limestone and others. These minerals have contributed to the growth and development of the country which have attracted several individuals into the exploitation in both legal and illegal manner (Mallo, 2007). Most of the mining activities are undertaken by artisanal miners which are seen as surface or artisanal mining. These are done with little or no technology adaptation to handle the damages of the mining activities (Oladipo, 2006). Increasing impact witness over the years was as a result of the fact that most of the miners undertake the activities illegally, that is without the required government license or permit. Most times, the mining areas are not known to the government and its agencies responsible for the regulation of mining activities (Ahmad,2008). This in turn makes it difficult for the government to monitor their operations in order to inflict environmental regulations on them. Similarly, the government may or may not have adequate records of land degraded during these operations in parts of the country or state where mining takes place. This makes future planning of policies of reclaiming, restoring and managing the mining environment difficult.

Mining refers to the process of extraction of mineral deposits from the surface of the earth or from beneath the surface (Obaje et al., 2005; Ako et al., 2014). Mining can only take place where minerals are present and economically feasible. The general importance of the mining sector has been documented to include foreign exchange, employment and economic development (Obaje and 


\section{International Journal of Engineering Applied Sciences and Technology, 2020 Vol. 5, Issue 1, ISSN No. 2455-2143, Pages 711-719 \\ Published Online May 2020 in IJEAST (http://www.ijeast.com)}

Abba, 1996; Nwajiuba, 2000). The mining sector in Niger State consists of the formal large scale subsector, the formal small scale miners and the informal small scale or artisanal small scale miners (Svotwa and Mtetwa, 1997). The later involves unskilled small scale, informal and usually illegal miners employ rudimentary methods and processes to extract mineral resources and who most times, have little or no knowledge of environmental issues (Phiri, 2012).

Artisanal mining has become livelihood adopted primarily in rural areas (Veiga, 2003). Globally, there are about 10 to 20 million persons involved in artisanal small-scale mining producing about $12 \%$ of the world's mining annually (UNEP, 2008). Minerals extraction in artisanal manners are people working with simple tools and equipment (Bradshaw et al., 1997). This is sometimes called informal sector, which is outside the legal and regulatory framework (Azubike, 2011). When not formalized, organized, planned and controlled, artisanal mining can be viewed negatively by governments and environmentalists, due to its potential for environmental damage, social disruption and conflicts (Opafunso, 2010).

Geographical Information System (GIS) are information systems that facilitate the capture, storage, manipulation, analysis, management and presentation of geo-referenced data. (Beunemann, 2009). GIS as a technique can be employed in the mining sector due to its capability of allowing a relatively high rate of public access to traditional information, such as environmental impact statements, studies and reports, significant environmental events and resources and census data. With respect to artisanal mining, GIS can be used to located where these activities are found and the extend at which it has affected the environment and man. GIS continues to be used as an effective planning tool, enabling users to access information relating to, among other things, existing conditions, environmental assessments, impact statements, transportation studies, and community studies.

GIS is a type of computerized mapping, yet it is not limited solely to map form because information about a location can be represented through charts, graphs or tables in ways that are unavailable to traditional paper maps (Heywood et al., 1998). A GIS system is designed to determine, capture, management, manipulation, analysis, modeling, and display of spatially-referenced data for solving complex planning and management problems. Its purpose is to store and analyze objects and phenomenon where geographic location is an important characteristic or critical to the analysis.

However, extraction of raw materials from their natural habitats by mining considerably affect the natural environment (Musa et al., 2019). Again, creating the pits or quarries requires the removal of virtually all-natural vegetation, top soil and subsoil to reach the aggregate underneath. Not only does this lead to a loss of existing animal wildlife, it also leads to a huge loss of biodiversity as plants and aquatic habitats are destroyed. Moreover, adjacent ecosystems are affected by noise, dust, pollution and contaminated water. Also, a working quarry needs methods of transportation and this means that large amounts of machinery and heavy traffic will be brought into the area, causing an increase in local noise, pollution and erosion. Despite the benefits, mining also has negative impacts. The blasting using fire for extracting minerals contributes greatly to pollution (noise, soil and air). Mining interferes with human settlement and wildlife habitat areas, leading to their displacement. mining also leads to death, where workers are buried by the rocks (North Stone, 2016).

Artisanal mining operations often times leave the affected environment severely degraded, physically and socially. There is also the health effect on both the miners and other living things. Degradation commonly occurs at all stages of mining activities from exploration to mine closure, resulting from both large and small-scale artisanal mining operations (Phiri, 2012). Until the 1970's environmental issues were not given serious and adequate consideration in mining policies by mining companies, government and the host communities. Environmental degradation was generally accepted as the price that had to be paid for the production of essential mineral commodities. High rate of unemployment and poverty has paved way for the invasion of the environment by intense artisanal miners. The main target of artisanal miners was to mine primary and alluvial gold deposits with little or no consideration for the environment, thus, expelling a lot of heavy metals associated with quartz as gangues and other sundry poisonous by-products into the environment and any available water source (Open wells and rivers) stressed that artisanal mining has caused a lot of negative impacts on the several communities of the Niger State.

Ahmad (2008) reported that artisanal mining operations are taking place in Kaduna, Niger, Kogi, Kwara, Oyo, Osun, Zamfara, Bauchi, Gombe, Taraba, Benue and Cross River States in Nigeria. 


\section{International Journal of Engineering Applied Sciences and Technology, 2020 Vol. 5, Issue 1, ISSN No. 2455-2143, Pages 711-719 \\ Published Online May 2020 in IJEAST (http://www.ijeast.com)}

Available records indicated that industrial metals: precious metal, precious and semiprecious stones are mined in these states and in varying quantities. There is also little or no literature on the illegal mining operations in some of these state (Bugaji, 2006). It is therefore important that mining operations in these States should be investigated, recorded and brought to the attention of the public and government for information and policy planning. Some of these menaces of illegal mining by artisanal miners includes depletion of the environment such as land degradation, vegetation, lost of aquatic animals, water pollution and air pollution. Most artisanal miners work in difficulties and often very hazardous conditions in the absence of the required safe mining regulations to safeguard the operations (Veiga, 2003). Apart from environmental problems, health issues are not left out because of artisanal and small-scale gold mining operations. The use of gravity concentration methods such as panning and sluicing during processing poses health problems.

Civilizations have ushered the modern man into exploration and exploitation of the natural environment with increasing sophistication in the tools and methods. The Industrial Revolution resulted in large scale exploitation of the world's resources (Mallo 2007) with resultant environmental degradation and socio-economic impacts (Nwuneli and Opubor, 1983; Goudie, 1997; Snihs and Akerblom, 1999; Ofomata 2001; Burden et al., 2002; Mudd, 2003; Asthana and Asthana, 2005; Taylor and Taylor, 2008). It is against this background that this research is aimed to provide empirical information on the locations artisanal mining sites in Niger State and its implication on the environment. To achieve this, the paper identified artisanal mining sites, examined the various mineral resources generated, highlight the implications on the environment and lastly provide recommendations

\section{What Literatures Says?}

Eshiwani (2014) studied the effects of quarrying activities on the environment in Nairobi county. The study found that regardless of the important role that quarrying activities played in the economic growth and has resulted into negative effects to the environment such as land degradation. Mwangi (2014) carried out an assessment of environmental impacts of quarrying activities in Ndarugo area, Kiambu county, Kenya. The study exposed that some of the quarry sites have been abandoned and the active quarry sites have numerous negative environmental impacts both bio-physical and socio- economic which affect both the people living in close proximity to the mining sites and the workers who work in the sites. Tagore et al. (2012) mapped degraded lands in Bhopal India using remote sensing and GIS techniques. The study concluded that three soil erosion categories namely sheet erosion, gullied, and stony waste were found. Sreenivasa and Reddy (2014) investigated socio-economic and environmental perception of inhabitants of a quarry area in Karnataka. The study revealed that many positive impacts were realized from a long-term quarry unit.

Afeni and Adeogun (2015) assessed communities company relation in limestone mining region of southwest Nigeria. The study found that the benefits derived by the host community are insignificant when compared with the negative effects of the exploitation on the community. Ujoh et al. (2014) executed Multitemporal change detection at a limestone mining and cement production facility in central Nigeria and observed that there is rapid decline in density and quality of vegetation cover within the study area. Omosanya and Ajibade (2011) evaluated the impact on quarrying on the inhabitants of Otere Village, Southwestern Nigeria. The study shown that the activities by the operator of the quarry in Otere village has adversely affected the villagers, their health standard have been compromised, their abode endangered, and their means of livelihood (farming) jeopardized.

\section{MATERIAL AND METHODS}

\section{Study Area}

The study covered the geographical area of Niger State which is located in the central part of Nigeria and the largest states in term of land mass in the country covering about $76,363 \mathrm{Km}^{2}$. The state has its capital in Minna and lies between Latitudes $9^{\circ} 30^{\prime} 00^{\prime}$ ' and $11^{\circ} 30^{\prime} 00^{\prime \prime}$ and Longitudes $3^{\circ} 00^{\prime} 00^{\prime \prime}$ and $8^{\circ} 30^{\prime} 00^{\prime \prime}$. The state is endowing with lots of natural and mineral resources which boasts of commercial quantity of large mineral deposit like gold, kaolin, tantatile, granite, marble, copper and lead. The state is comprising of 25 Local Government Areas. The choice for the study area was based on the effects of artisanal activities has caused on the environment both on the vegetation, climate and water bodies.

Niger State is one of the states in the North-Central region of Nigeria. Its endowed with amazing solid mineral resources that have great potentials to turn the economy of the state and favorably compete with oil producing states in the South-south region. However, the state is faced with the activities of 


\section{International Journal of Engineering Applied Sciences and Technology, 2020 \\ Vol. 5, Issue 1, ISSN No. 2455-2143, Pages 711-719 \\ Published Online May 2020 in IJEAST (http://www.ijeast.com)}

artisanal mining by some people within the state and others from different parts of the country including foreigners believed to be sponsored by money-bags who were into the activities. The state is blessed with Gold, Talc, Kyanite, Kaolin, Ball clays, Graphite, Feldspar, Marble and Dolomite, Manganese; Mica, Lead and
Copper, Quartzite, Asbestos, Iron, Silica sand, Granite, Gemstones (varieties). These minerals are available in commercial quantities and can be used for both domestic and export markets if only when fully utilized in a right direction.

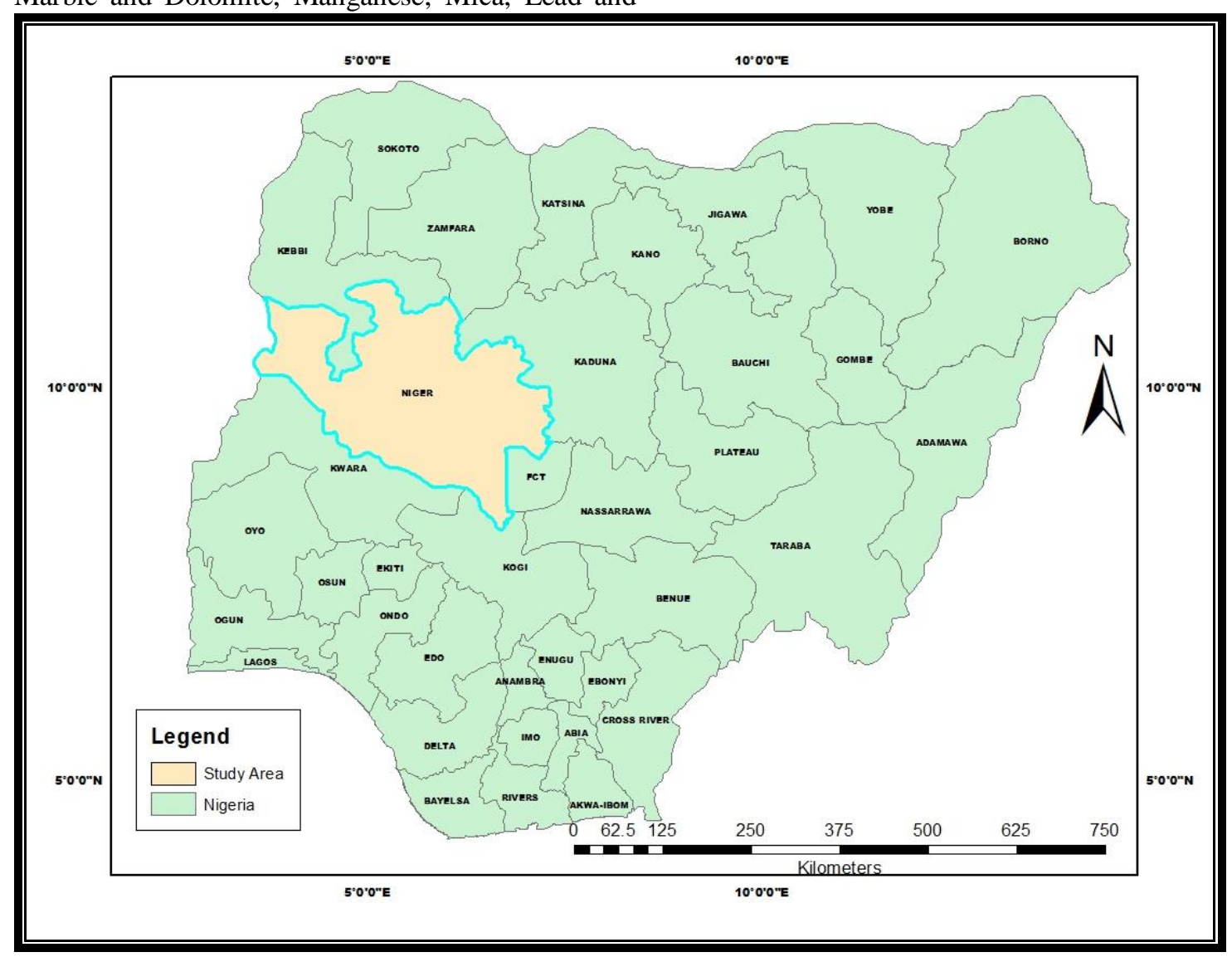

Figure 1: Niger State in Nigeria Source: Department of Geography, NDA, Kaduna (2018)

\section{METHODS}

The study utilized coordinates of the location of the artisanal miners, interview with both miners and government officials while the secondary data was generated from documented materials from Ministries, Department and Agencies (MDAs), existing published in articles to investigates the implications of artisanal mining activities. Personal observation was also adapted to obtained additional information's on the processes involved in the activities and how it has affected the environment. Artisanal mining site in Niger State were highlighted and mapped to show the spatial location of the activities. The coordinate derived from handheld GPS were inserted on excel and later incorporated into ArcGIS software to show the distribution of the artisanal mining sites in Niger State. Further explanations were given based on interviewed conducted and observation undertaken to explain the implication of the activities to the environment.

\section{RESULTS}

The study identified and located nineteen (19) artisanal sites in Niger State mapping as shown in Table 1.

Table 1: Artisanal Mining Site and Minerals Mined in Niger State 


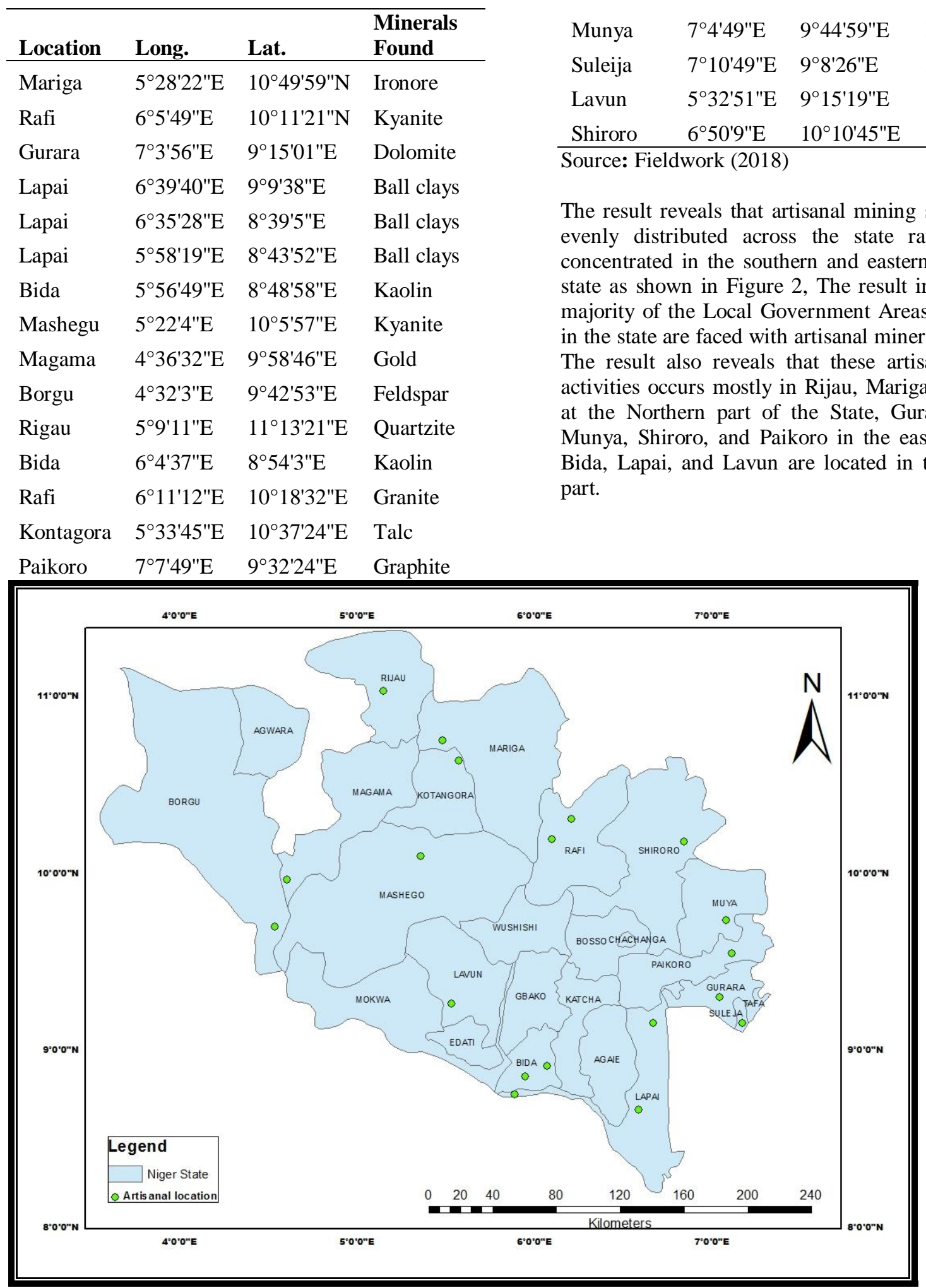

Figure 2: Location of Artisanal Mining Sites in

Source: Fieldwork (2018)

Niger State 


\section{International Journal of Engineering Applied Sciences and Technology, 2020 \\ Vol. 5, Issue 1, ISSN No. 2455-2143, Pages 711-719 \\ Published Online May 2020 in IJEAST (http://www.ijeast.com)}

The study reveals that artisanal mining is carried out using local implement like hoes, shovel, diggers and even bush burning as shown in Plates 1 and 2. The study reveals that artisanal mining sites are in Mariga (where Galena is mined); Graphite in Paikoro and Minna; Iron Ore in Kontagora, Bida and rafi; Kaolin in Bida, and Lavun; Kyanite in Shiroro and rafi; Marble in gurara; Talc in Kontagora. Further probe also exposes that extraction of these minerals in Niger State can be traced back to year 1911. Niger State is blessed with so many minerals scattered across the state. The implications of these are uncontrolled mining with little or no sustainable ideals and environmental management. The result further reveals that the unsecured mining in Niger State have exposed the environment to serious hazards like the generation and uncontrolled discharge of enormous amounts of toxic wastes which impact adversely on the human health and the ecosystem. Extraction of sands, gravels, clay, tin, limestones, and mineral resources has affected the environment. Niger State which is due to be developing is faced with environmental problems from miners.

The activities of these artisanal miners as alter the physical nature of the environment. This can be seen in most of the Plates 1 and 2 where the top and nutritious part of the soil are been altered where the nutrient are been carried away as a result of digging of pits and tunnels (lotos), dumping of debris heaps and quarrying.

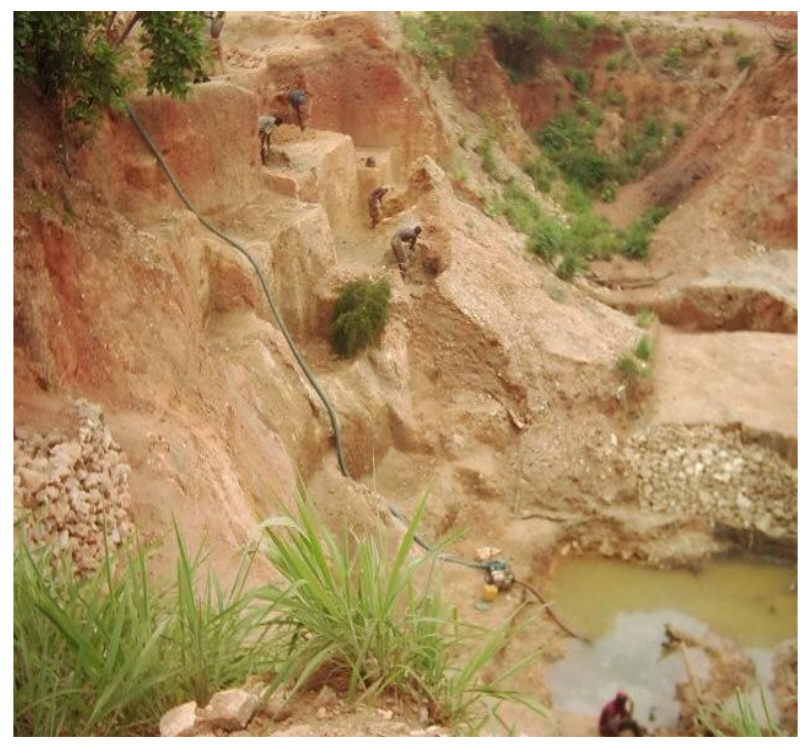

Plate 1: Artisanal Mining Iron Ore in Kontagora Source: Fieldwork (2018)

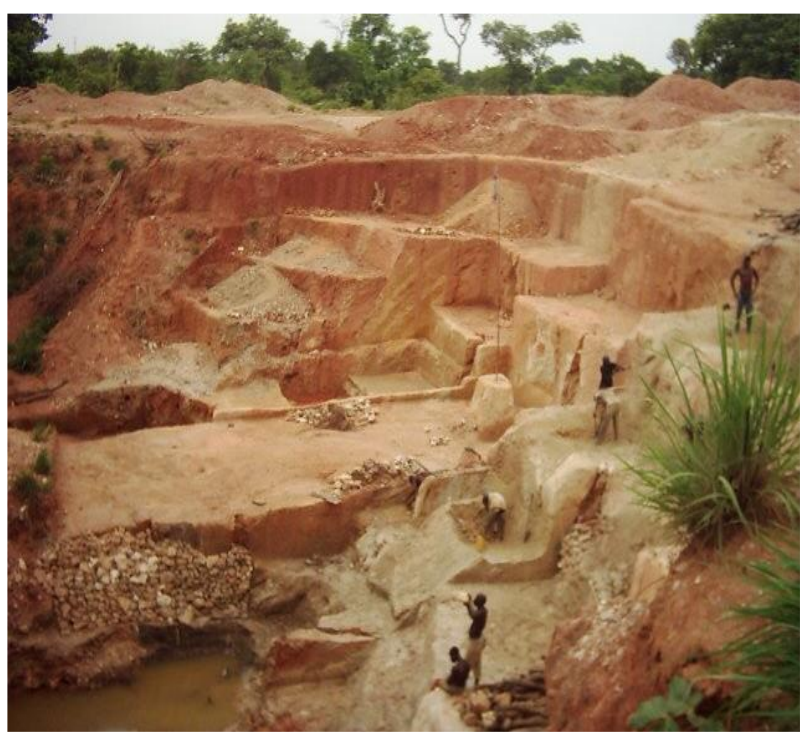

Plate 2: Artisanal Mining Iron Ore in Bida

Source: Fieldwork (2018)

The miners after digging and extraction of minerals leave the area unreclaimed their by causing serious erosion (Plates 3 and 4).

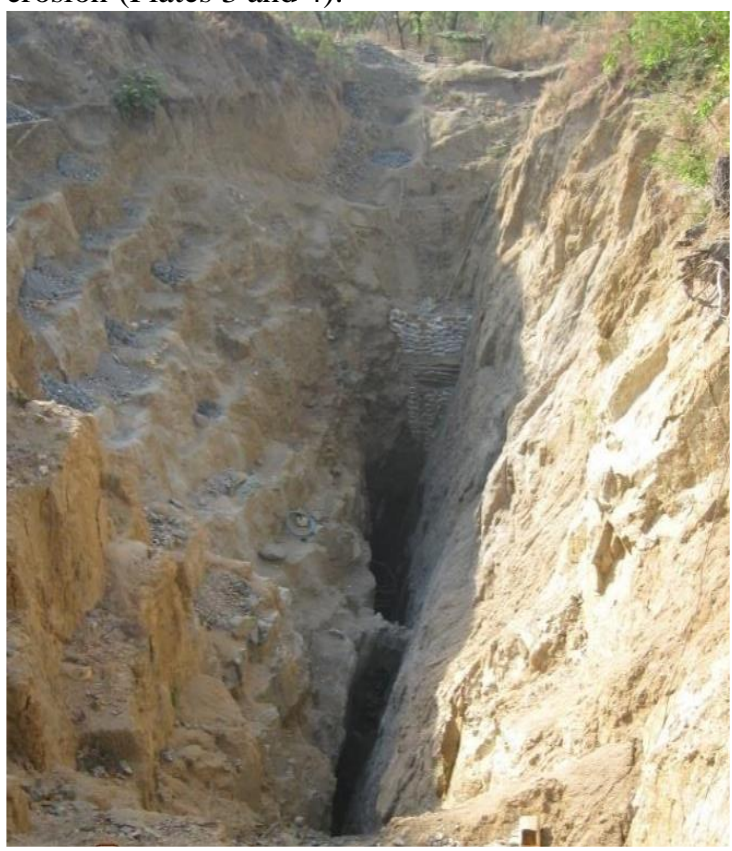

Plate 3: Artisanal Mining Iron Ore in Kontagora Source: Fieldwork (2018) 


\section{International Journal of Engineering Applied Sciences and Technology, 2020 \\ Vol. 5, Issue 1, ISSN No. 2455-2143, Pages 711-719 \\ Published Online May 2020 in IJEAST (http://www.ijeast.com)}

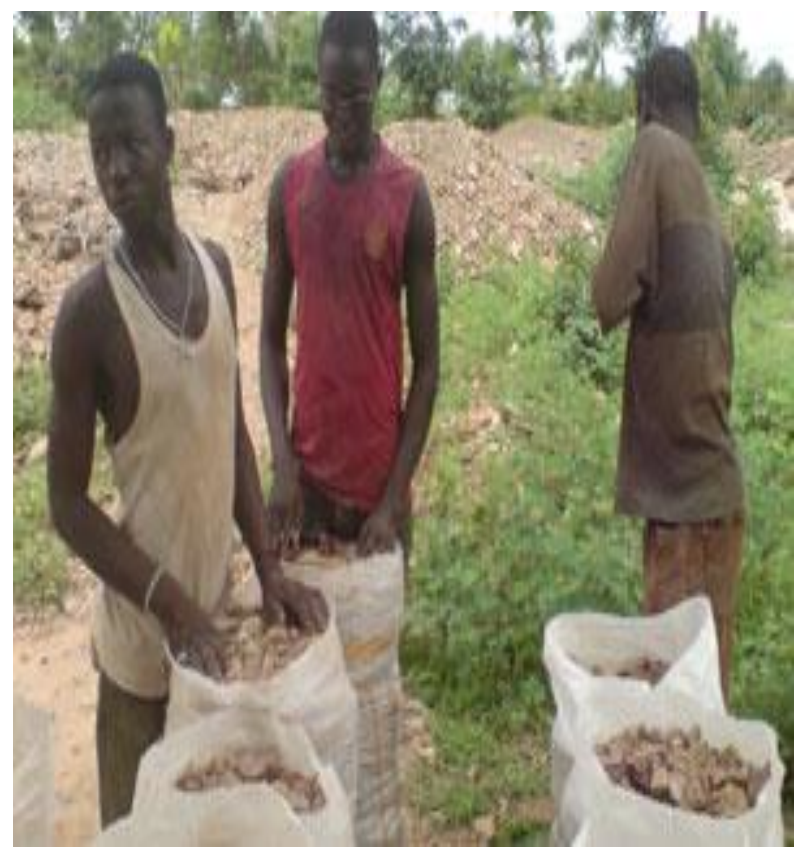

Plate 4: Artisanal Mining Iron Ore in Kontagora Source: Fieldwork (2018)

The result shows that artisanal mining involves the miners create harmful effects as a result of digging the minerals come in contact with water bodies thereby releasing heavy and poisonous metals contain in the rocks as gangus are deposited (Plates 5 and 6). This might result in polluting the water bodies and the underground water.

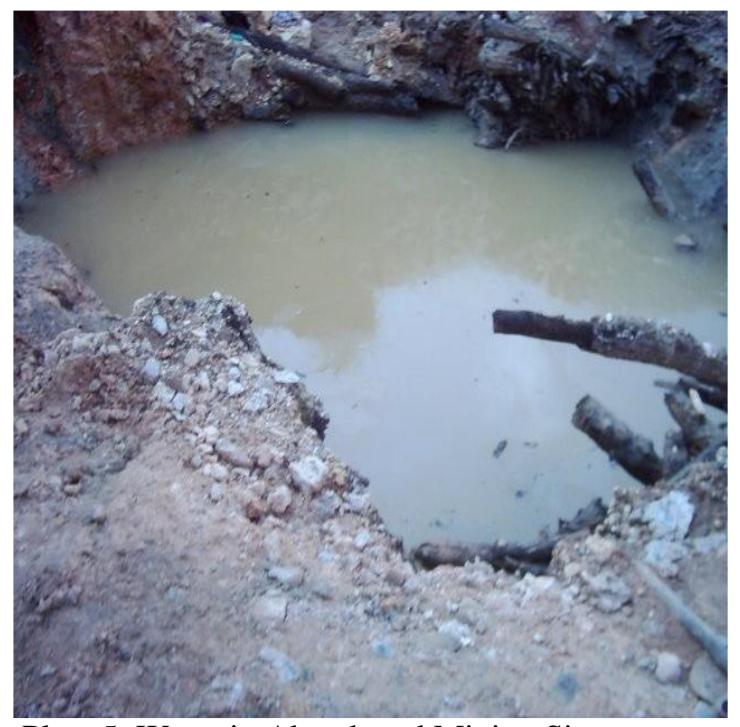

Plate 5: Water in Abandoned Mining Site Source: Fieldwork (2018)

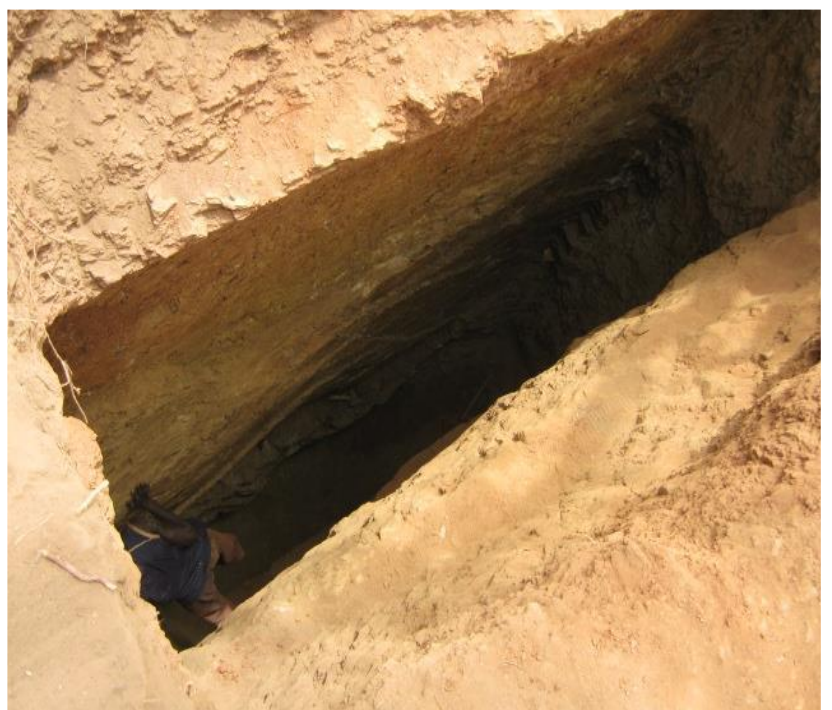

Plate 6: Heavy Earth Removal by Miner Source: Fieldwork (2018)

Effects on Biological Environment: The result also shows that artisanal miners create lots of noise in the process of mining particularly in the process of drilling of minerals under the rocks. The vibration natures in the process of mining affect the settlement around the areas where mining takes place for example in Bida area most settlement around the mining site tends to relocate to other areas. Also included on the effects are those created to the fauna. The noise and vibration created affect the animals to be forced out of their natural habitat to other location and the vegetation cover are been cleared for mining activities.

Effects on the Geology: The activities by the artisanal miners in Niger State as affected the geological environment which has trigger certain geological problem such as subsidence, flooding, erosion, landslide and landslide. Some building around the mining site such as in munya in 2011 was damaged by developing cracks due to frequent blasting of the rocks.

\section{CONCLUSION AND RECOMMENDATION}

This paper has assessed that spatial locations of artisanal mining in Niger State, Nigeria through field survey and mapped the distribution of these sites. The study discovered 19 artisanal mining sites around the state. The study found out that the activities of artisanal miners, who are mostly rural dwellers are sitting on a keg of gun-powder that could consume 


\section{International Journal of Engineering Applied Sciences and Technology, 2020 Vol. 5, Issue 1, ISSN No. 2455-2143, Pages 711-719 \\ Published Online May 2020 in IJEAST (http://www.ijeast.com)}

thousands of lives. The study also discovered that the serious degradation of the environment caused by these desperate money seekers. It is no longer news that the environment that provides people with necessities of life is face with the artisanal miners who uses local implement in the mining thereby creating a lot of impact to it which includes destruction of vegetations, changing the geological nature of the environment, effects on the water bodies. This paper has therefore recommended the use of legislation to avert further degradation of the environment, government should also provide infrastructures and social amenities, providing security checks on artisanal miners.

\section{REFERENCE}

Ahmed, Y. M. (2008). Personal Communication. Chief Scientific Officer, Ministry of Solid Mineral Development.

Ako, T. A., Onoduku, U. S., Oke, S. A., Adamu, I. A., Ali, S. E. and Ibrahim, A. T. (2014). Environment Impact of Artisanal Gold Mining in Luka, Minna Niger State, Northwestern Nigeria.

Asthana, D. K. and Asthana, M. (2005). Environment: Problems and Solutions, S Chand Company, New Delhi, India.

Azubike, A. L. (2011). The Technology of Peaty Soils in Mozambique and Angola, Transactions of the $5^{\text {th }}$ International Congress of Soil Science, Leopoldville 3: (pg: 398-401).

Bradshaw, A. D. (1997). Restoration of Mined Lands - Using Natural Process, Ecological Engineering, 8 (Pg. 255-269).

Bugaji BM (2006). Final Report on Action Plan for Artisanal and Small Scale Gypsum Mining Pilot Project, Nafada, Gombe State, Unpublished Technical Report Presented to Ministry of Solid Mineral Development, Abuja, Nigeria.

Burden, F. R., Kelvie, M. C., Forstner, U. and Guenther, A. (2002). Environmental Monitoring Handbook, McGraw-Hill, USA.

Eshiwani, F. (2014). Effects of Quarrying Activities on the Environment in Nairobi County: A Case Study of Embakasi District, Master Thesis, University of Nairobi.

Goudie, A. (1997) The Human Impact on the Natural Environment. The MIT Press, Massachusetts, USA, (Pg. 243-378).

Heywood. I. and Cornelius. S.; and Carver,S. (1998). An Introduction to Geographical Information Systems, Longman Pub., (Pp.279-280).

Mallo IIY (2007) Environmental and Socio-economic Effects of Tin Mining on the Jos Plateau, Nigeria,
Abuja Journal of Geography and Development, (Pp.142-159).

Mudd GM (2003) Uranium Mining in Australia: Environmental Impact, Radiation Releases and Rehabilitation; International Atomic Energy Agency, Vienna, Austria, (Pg:179-189).

Musa S, Ezeamaka CK, Adewuyi TO, Daful MG (2019) Spatio-Temporal Assessment of Quarry Sites in Mpape, Abuja, Nigeria. J Remote Sensing \& GIS 8:255. doi:10.4172/2469-4134.1000255.

Mwangi, S. N. (2014). An Assessment of Environmental Impacts of Quarrying Activities in Ndarugo Area, Kiambu County. (Bachelor Degree Project - Kenyatta University. Retrieved from: http://www.ir-

library.ku.ac.ke/handle/123456789/12809.

North Stone (2016). Quarrying Process and Quarry Products. Retrieved from: http://www.northstonematerials.com/quarrying_proce ss_and_quarry_products.

Nwajiuba, C.U. (2000). Socio-Economic Impact of Solid Minerals Prospecting on host Communities. A Study of Okaba, Kogi State,Nigeria, Technical Report to the Nigerian Coal Corporation, Enugu, Nigeria, (Pg 59).

Nwuneli OE and Opubor A (Ed) (1983). Environmental Awareness for Media Practitioners. A Nigerian Workshop, Federal Ministry of Housing and Environment, Seagul Publishers, Lagos, Nigeria.

Obaje, N. G. and Abaa, S. I. (1996). Potential for coal-derived gaseous hydrocarbons in the Benue Trough of Nigeria. Petroleum Geol., 19: (Pg 77-94).

Obaje, N.G., Nzegbuna, A.I., Moumouni A. and Ukaonu, C. E. (2005). Geology and Mineral Resources of Nasarawa State, Nigeria. A Preliminary Investigation. Paper Presented at the 4th Nasarawa State Agricultural and Solid Minerals Exposition held at Agyaragu, Nasarawa State, Nigeria, 21-23 March, (Pg. 1-27).

Ofomata GEK (2001) Environment and Development, A Valedictory Address, University of Nigeria, Nsukka, (Pg:1-20)

Oladipo S.O (2006). Status of Nigerian Mineral Resource Industries (ASSM Perspectives). Being a Presentation at the Nigerian Mining and Geosciences International Conference, Kaduna.

Omosanya, K. O. and Ajibade, O. M. (2011). Environmental impact of quarrying on Otere village, Odeda, South-western Nigeria; Ozean Journal of Applied Sciences, Vol 4(1). Retrieved from: http://www.scholar.google.com/citations?user=qLz7d MMAAAAJ\&hl=en.

Opafunso, Z. O. (2011). Overview of Artisanal and Small Scale Mining of Gold Operations in Nigeria. 
Lecture at Federal University of Technology, Akure, Ondo State, Nigeria.

Phiri, S. (2012). Impact of Artisanal Small Scale Gold Mining in Umzingwane District (Zimbabwe), a Potential for Ecological Disaster. M. Sc Thesis, Disaster Management Training and Education Centre for Africa, University of the Free State, Zimbabwe.

Snihs, J. O. and Akerblom, G. (1999). Use of Depleted Uranium in Military Conflicts and Possible Impact on Health and Environment, Swedish Radiation Protection Institute, SE-17116, Stockholm, Sweden, (Pg:1-9)

Sreenivasa and Reddy, R. (2014). Socio-Economic and Environmental Perception of Inhabitants of a Quarry Area - A Case Study of Bidadi, Bangalore Rural District. International Journal of Engineering Science Invention. Vol. 3 (4). Retrieved from: http://www.ijesi.org/papers/Vol(3)4/Version4/B0344011022.pdf.

Svotwa R, Mtetwa C (1997). The Environmental Impacts of Small-Scale Mining in Zimbabwe. Proceedings of the 1997 Conference of Mining, Minerals and Sustainable Development, Harare, ITDG.

Tagore, G. S., Bairagi. G. D., Sharma, N. K., Sharma, Sharma, R., Bhelawe, S. and Verma, P. K. (2012). Mapping of Degraded Lands Using Remote Sensing and GIS Techniques. Journal of Agricultural Physics. Vol. 12 (1). Retrieved from: http://www. agrophysics.in/Published/2012/4-GS-Tagore.pdf.

Downloaded on: 6 August, 2016.

Taylor, D. M. and Taylor, S. K. (2008) Environmental Uranium and Human health; http://www.ncbi.nlm.nih Gov/pubmed/94062865/12/2008.

Ujoh, F., Alhassan, M. M. and Ujoh, F. T. (2014). Multi-Temporal Change Detection at a Limestone Mining and Cement Production Facility in Central Nigeria. American Journal of Environmental Protection, $3 \quad$ (3) $\quad(\mathrm{Pg} \quad 3), \quad$ doi: 10.11648/j.ajep.20140303.12

Veiga, M. M. (2003). Mercury in Artisanal Gold Mining in Latin America: Facts, Fantasies and Solutions, UNIDO Expert Group Meeting Introducing New Technologies for Abatement of Global Mercury Pollution Deriving from Artisanal Gold Mining, Vienna, Austria.

Acknowledgement: To all members of Staff of Department of Geography, NDA, Kaduna, Nigeria 